\title{
CONTRIBUCIÓN AL ESTUDIO DEL URBANISMO ANTIGUO EN EL BAJO GUADALQUIVIR: EL CASO DE LEBRIJA (SEVILLA)
}

\section{CONTRIBUTION TO THE STUDY OF ANCIENT URBANISM IN THE LOWER GUALDALQUIVIR VALLEY: LEBRIJA (SEVILLA) AS A CASE-STUDY}

\author{
por \\ JOSÉ MARÍA TOMASSETTI GUERRA
}

RESUMEN Ofrecemos en este trabajo una interpretación histórico-arqueológica de la ciudad de Lebrija a partir de la reconstrucción paleogeográfica de su entorno inmediato, la constatación de las primeras evidencias de poblamiento estable y su surgimiento como centro urbano. Basándonos en fuentes escritas, arqueológicas y documentos gráficos, presentamos nuestras actuales hipótesis para el oppidum turdetano, el municipio romano y la villa medieval.

\begin{abstract}
We offer in this work a historical and archaeological interpretation of the city of Lebrija, from the palaeogeographical reconstruction of it's hinterland, the verification of their first evidences of permanent settlement and it's origin as an urban center. According to written and archaeological sources, and to graphical documents, we present our current hypothesis for the turdetan oppidum, roman town and medieval villa.
\end{abstract}

El desarrollo adquirido por la Arqueología Urbana en Andalucía en los últimos años ha permitido la proliferación de estudios puntuales en cierta limitada cantidad de municipios cuya evolución urbanística más se intuía que se conocía. Estos trabajos, sin embargo, han sido más el reflejo de la eclosión de ciertas "arqueologías" de corte administrativo (arqueología de gestión, contractual...) que el fruto de verdaderos proyectos organizados de investigación, de manera que en su mayoría han terminado por contribuir escasamente al esclarecimiento de los interrogantes que cada localidad, cada yacimiento urbano, planteaba. Excepciones aparte, casi siempre se ha intervenido en ellos por la vía de emergencia, a menudo bajo la dirección de profesionales cuyas formación y capacidad quedan fuera de toda duda, pero que no disponían ni de la información ni del tiempo necesarios para rentabilizar científicamente el resultado de sus actuaciones. Al final, la relativa profusión de publicaciones apenas termina siendo útil a menos que sean más tarde retomadas y revisadas a la hora de programar estudios de carácter sistemático. 
Por otro lado, la multiplicación de excavaciones de urgencia no ayudó a diversificar las líneas de trabajo pues, desde el primer momento, fueron acaparadas por los arqueólogos provinciales y tenían lugar preferentemente en las capitales de provincia. Con lentitud parece que la nueva conciencia empresarial de los arqueólogos andaluces, al hilo de las posibilidades que los Planes Generales de Ordenación abren a los profesionales autónomos, permite que la adjudicación de los trabajos salte las bardas del corral de la Administración Pública, pero aún es mínimo el avance en los pequeños municipios, como Lebrija (con menos de 25000 habitantes), en relación directa con el estancamiento de las políticas urbanísticas, a menudo dependientes de Normas Subsidiarias cuya reglamentación para la protección del Patrimonio Histórico no afecta más que a los monumentos que, en su día, fueron declarados Bienes de Interés Cultural ${ }^{1}$.

De todo ello resulta que el conocimiento de la evolución de los espacios urbanos desde su implantación original sólo se va organizando en las grandes ciudades (donde el volumen anual de edificación hace viable la existencia de empresas privadas de la rama de la Arqueología) y en otras menores tradicionalmente vinculadas al turismo patrimonial o que poseen museos o grandes yacimientos "clásicos" desde donde se canaliza la investigación de sus respectivos solares municipales (Córdoba, Carmona, Jerez o Santiponce pueden ser ejemplos válidos para cada caso). Lo habitual es, no obstante, que los pequeños y medianos centros urbanos hayan sido obviados por la investigación salvo que pertenecieran a comarcas cuyas cartas arqueológicas se llevaron -o se llevan- a cabo. El panorama actual para, por ejemplo, conocer las características específicas del urbanismo romano en las ciudades de la Bética, la provincia hispana con mayor densidad de asentamientos, es todavía deficiente, en tanto todas las inferencias posibles se hacen de la organización de las principales de ellas (Itálica, Bolonia, Corduba, etc.) o aplicando esquemas generales al mundo romano que pocas veces saben explicar con éxito las particularidades de cada municipio.

En concreto, la investigación histórico-arqueológica para Lebrija-ciudad en el presente siglo se inicia muy temprano por la labor de D. Luis López-Quiroga Salguero, que vierte en publicaciones de tirada local parte de sus impresiones, pero, estamos seguros, sin que haya trascendido gran parte de sus anotaciones, tal vez conservadas en el archivo familiar del que fue cronista local, ya difunto, D. José Bellido Ahumada ${ }^{2}$, quien en 1945 había terminado la primera edición de La Patria de Nebrija (Noticia Histórica). Entre 1945 y 1971 , fecha de la $2^{\mathrm{a}}$ edición de esta obra, conocidos arqueólogos del momento inician una corta serie de aportaciones con artículos referidos a hallazgos casuales (un ídolo cilindro calcolítico-Esteve 1961-, los llamados "candelabros" tartesios -Almagro 1964-y algunos fragmentos de sarcófagos paleocristianos -Bendala 1971-). Quizá debido al interés que se iba despertando en el Bajo Guadalquivir en torno a determinados temas (en 1968 tuvo lugar el famoso Simposio sobre Tartessos, en Jerez) y ante lo llamativo de algunos de los hallazgos citados, se inician los trabajos de campo en 1977, procediendo A. Tejera Gaspar a la excavación del que fue Huerto Pimentel, al Noroeste de la ciudad, lugar hoy invadido por la desordenada urbanización que se produjo en los años inmediatamente posteriores en las traseras del Castillo. Tejera publicó sus resultados en el Noticiario Arqueológico Hispánico $\left(\mathrm{n}^{\circ} 26,1985\right)$, habiéndolos presentado anteriormente en Lugo con motivo del $\mathrm{XV}^{\circ}$ Congreso Nacional de Arqueología (Zaragoza 1979). La provechosa visita del Padre Recio a nuestra localidad y su toma de contacto con J. Bellido y A. Caro Bellido, quien por entonces ya había comenzado la prospección del término municipal (entonces abarcaba también el del Cuervo, segregado posteriormente), dio sus frutos en varios trabajos fundamentales para el estudio de los materiales arqueológicos, epigráficos mayormente, de la ciudad tardorromana y visigoda (especialmente Recio 1979).

1. Para Lebrija, se está redactando el P.G.O.U. que incluirá una Normativa de Protección del Patrimonio Arqueológico, ya elaborada (Tomassetti y Caro, inédito).

2. De López-Quiroga conocemos los extractos que J. Bellido utiliza en su libro (Bellido 1985), procedentes de un artículo titulado "Recuerdos Históricos". El Látigo, n 1 (Agosto, 1901), que no hemos sabido localizar en las hemerotecas, pero que en 1928 aparece, dividido en varias entregas, en el Diario de Lebrija. 
En la década de los ochenta arranca una nueva fase de la investigación inaugurada con la conclusión de la Carta Arqueológica de Lebrija, contribución del citado A. Caro al proyecto, nunca terminado, del Departamento de Prehistoria y Arqueología de Sevilla que pretendía el estudio prospectivo de toda la provincia ${ }^{3}$. La actividad de este investigador (hoy profesor del Departamento de Historia, Geografía y Filosofía de la Universidad de Cádiz) ya no ha cesado, y a él debemos un gran número de artículos y monografías que, en aquellos años, dedicó especialmente al análisis del Calcolítico y la Edad del Bronce en la margen izquierda del Guadalquivir o a determinados aspectos materiales y hallazgos de interés. Con su trabajo de 1986-87 "Nabrissa (Lebrija, Sevilla). Los orígenes del núcleo urbano" ${ }^{4}$ sienta las bases de lo que será la nueva reflexión histórico-arqueológica de la ciudad hasta la actualidad. Haciéndose, en parte, eco de estos estudios, llega hasta nosotros la tercera y última edición, ampliada y revisada, de La Patria de Nebrija en $1985^{5}$. Desde este momento la historia de la arqueología lebrijana casi queda resumida en el curriculum de A. Caro, salvo excepciones puntuales (González 1982; o Ponsich 1991 -que en su mayoría aprovecha los datos ya aportados por A. Caro-).

Este aumento de la tensión investigadora propicia que en 1986 se acometa de nuevo una excavación, la "prospección con sondeo" del solar de la Calle Alcazaba, dentro del casco histórico, en colaboración de las Universidades de Cádiz y Sevilla por medio de sus profesores A. Caro, P. Acosta Martínez y J.L. Escacena Carrasco, que la dirigen, y de Manuel Pellicer Catalán, que coordina todas las tareas (él mismo dirigió la Tesina y la Tesis Doctoral de A. Caro Bellido). Sus resultados iniciales nos muestran una secuencia estratigráfica amplísima, desde momentos quizá anteriores al Neolítico hasta la actualidad (Caro, Acosta y Escacena 1986). La campaña de 1987, ya como actividad sistemática, no pudo cumplir las expectativas fijadas debido al mal tiempo. La falta de subvenciones económicas detuvo los trabajos en los años subsiguientes hasta que a finales de 1995 se entregó el informe preliminar del estudio de los materiales de 1986, en la campaña de estudios de 1994 (Caro, Acosta y Tomassetti e.p.). Al mismo tiempo que acaban las excavaciones de C/ Alcazaba sale a la luz el diagnóstico del Conjunto Histórico Artístico de Lebrija que la Dirección General de Urbanismo encargara al arquitecto A. García de Jalón, donde se aborda el estudio geográfico y morfológico de la ciudad y su evolución histórica hasta el presente. Nuestra comunicación es deudora en cierto modo del análisis que en él se hizo, y sobre su documentación gráfica hemos compuesto los distintos planos de que la acompañamos (García de Jalón 1987).

Pendiente de que los análisis de materiales procedentes de las excavaciones de 1986 y 1987 queden concluídos, ya existe un estudio de conjunto que los incluye parcialmente y proporciona una visión dinámica del entorno de Lebrija desde las primeras evidencias paleolíticas ${ }^{6}$ (Caro 1991). En los últimos años hemos intentado abordar ordenadamente la arqueología urbana de Lebrija, para lo cual solicitamos un Proyecto General de Investigación a la Consejería de Cultura de la J.A. en 1994, aún pendiente de resolución definitiva. Mientras tanto éste termine, o no, de concederse, hemos proseguido con esta línea de investigación a nivel teórico en un par de trabajos muy recientes (Tomassetti 1996 y 1997), colaborando con otros investigadores

3. La Carta fue leída por su autor, como Tesina de Licenciatura, en 1981. Aún inédita, existe un resumen de ella en el tomo de 1984 que la Universidad dedica anualmente a recensiones de tesis y tesinas. Vid. bibliografía.

4. Anales de la Universidad de Cádiz, III-IV: 55-70. Nos ahorraremos ofrecer en la bibliografía la lista completa de las publicaciones del Dr. Caro, haciendo referencia sólo a las que consideramos de obligada consulta para el tema que nos ocupa.

5. Edición póstuma que celosamente se encargó de preparar la hija del autor, $\mathrm{D}^{\mathrm{a}}$ Carmen Bellido García de Atocha. El resultado final es un libro surgido de toda una vida de indagación en los archivos locales, con multitud de datos no siempre bien organizados pero utilísimos al investigador de la historia de la ciudad. Lamentablemente esta línea de trabajo archivístico no ha encontrado seguidores capaces de organizar un mínimo esquema que explique coherentemente el devenir de Lebrija en los siglos medievales y modernos, salvo el estudio demográfico del XVIII de M.J. Fernández (1996). Para la edad contemporánea, y sólo en parte, puede servir el trabajo de Pulido (1992) o, desde la perspectiva de la antropología social, el de Talego (1996).

6. Existen restos de industria achelense en el cercano yacimiento de San Benito así como en la Fuente de La Salud (Jerez). Los primeros se encuentran en fase de estudio y esperamos poderlos dar a conocer en un futuro próximo. 
cuando se ha presentado la ocasión, caso de la excavación de urgencia del Hospital de la Misericordia (1994) por J.M. Huecas Atenciano, cuyo informe permanece en prensa (Huecas e.p.). La contribución que pretendemos hacer en estas páginas es avance de un trabajo más ambicioso que presentaremos como Memoria de Licenciatura en la Universidad de Cádiz.

\section{ANÁLISIS DE LAS FUENTES}

Lejos de pretender una exposición exhaustiva de la documentación actualmente conocida alusiva a los distintos aspectos de la organización espacial de Lebrija desde su constitución como núcleo urbano, sus aportaciones y deficiencias, ensayaremos una ordenación básica según su procedencia.

Fuentes Escritas: las obras reseñadas en los párrafos introductorios, especialmente las de J. Bellido y A. Caro, proporcionan una guía de las referencias debidas a autores clásicos. Junto a las de Estrabón, Plinio y Ptolomeo, más o menos generales, destacan las noticias de Silio Itálico respecto a la fundación mítica de la ciudad por Baco. Las Crónicas Medievales son parcas en sus referencias a Lebrija, salvo el Al-Muqtabis de Ibn Hayyan y algunas menciones de pasada entre otros autores musulmanes, caso del Rawd-alQuirtas. Entre las cristianas, aparecen a partir de la de Fernando III, cuando la toma de Sevilla, momento en que se inicia la Reconquista y Repoblación de la comarca gaditano-xericiense. Sin embargo, no es hasta el Renacimiento que obtenemos información válida para sacar conclusiones sobre aspectos urbanísticos concretos a través de los comentarios de autores como Elio Antonio de Nebrija ${ }^{7}$, J. Mal-Lara, F. de Ocampo, A. de Horozco o el Padre Mariana. Sus aportaciones tienen valor relativo en tanto apenas ayudan a la organización efectiva del viario o espacios públicos, limitándose a evidenciar la existencia de elementos arquitectónicos destacados, como el arco que hubo en la actual Plaza de España. Basándose en unos y otros, así como en su conocimiento directo de la villa, Rodrigo Caro recopila el corpus documental que ha de servir de guía a los autores del XVIII, caso de A. Ponz en su Viaje de España, y del XIX (Madoz, Ceán Bermúdez, Antón...), repitiéndose casi siempre los mismos asuntos: origen mítico y restos romanos.

Textos clásicos, Crónicas Medievales y autores moderno-contemporáneos hasta el XIX, en conjunto, nos advierten de la existencia de un oppidum turdetano y establecimiento romano (Nabrissa-Veneria), prácticamente desconocido tras la invasión musulmana del 711 , con un castillo desde al menos el siglo IX, cuyos restos aún se conservaban en parte en los siglos XVI-XIX. Ninguno alcanza la precisión de las descripciones de López-Quiroga (1901), quien nos ofrece la delineación de una muralla "en forma de herradura", la descripción y ubicación de las puertas, con sus nombres, y otros detalles, datos todos que podemos referir a los límites de la ciudad medieval entre los siglos XIII al XV, antes de verse desbordados por los nuevos barrios construídos tras el cese progresivo de hostilidades de los moros granadinos. Para la ciudad del Renacimiento y posterior, el complemento informativo nos viene de la documentación archivística. Aún pendiente de estudios precisos, tenemos la notable contribución de J. Bellido en su Capítulo XII, "Calles y Plazas de Lebrija" (Bellido 1985: 431-481), que nos ha servido de base para elaborar el plano posible del siglo XVI (fig. 8).La bibliografía más reciente, ya comentada, completa poco a poco el panorama inicial sobre el que se basarán nuestras hipótesis.

En resumen, la información efectiva queda referida al recorrido de la muralla entre las calles Sanlúcar y Meneses y Portales (como se ve en la fig. 5); a la localización de las puertas, con sus nombres medievales: P. de Santiago (fig. 5: $\mathrm{n}^{\circ}$ 1), P. de Sevilla (2), P. de Rota o del Aceituno (3) y P. de Jerez (4); y, completando el recinto defensivo, un foso excavado donde después se encajó la C/ Cataño (5).

7. Sobre este autor, vid. Caro y Tomassetti (1997). 
Fuentes Arqueológicas: la escasa atención que han despertado los hallazgos casuales producidos, así como su destrucción, sólo nos permite ubicar en la cartografía las noticias que se nos han transmitido, a menudo sin una significación específica (trozos de columnas, ladrillos...). Sólo relacionamos ahora aquéllos capaces de orientarnos en algo sobre el asunto que nos ocupa:

- (6) Restos de mosaicos y columnas en el Convento de Monjas Concepcionistas (noticia de R. Caro que recoge Bellido $1985^{8}$ ).

- (7) Restos de un ancho muro de ladrillo y hormigón, con dirección Este-Oeste, en C/ Empedrada, 9 (Bellido 1985).

- (8) 6 fustes de columnas ("Tambores del Castillo") y parte de una ménsula en la ladera norte del Castillo (Caro 1981; Bellido 1985).

- (9) Restos de un ancho muro en dirección Este-Oeste en Callejón del Lelo (Tomassetti 1996).

- (10) Restos de inhumaciones entre el Callejón del Lelo y C/ Meneses y Portales (Tomassetti 1996).

- (11) Necrópolis tardorromana en C/ Cataño (Bellido 1985).

- (12) Restos de edificios y esculturas romanas en la confluencia de las calles Antonio de Nebrija e Ignacio Halcón (Caro 1981).

Además, en el recorrido actual de las calles podemos constatar la presencia de interesantes estructuras ${ }^{9}$ : - (13) Paño de muralla entre los números 9 y 11 de C/ J. Sánchez de Alva.

- (14) Escasos restos de muralla entre el Callejón del Lelo y la Cuesta del Guineo.

- (15) La propia Cuesta del Guineo, en cuyo trazado pervive la planta de una puerta en recodo (García de Jalón 1987 la constata, aunque no llega a caracterizarla).

- (16) Restos de una torre de tapial en la ladera Sur del Castillo.

Por último, poseemos los datos derivados de la interpretación que haremos de las excavaciones de Huerto Pimentel (17) (Tejera 1977 y 1979), y el Solar de C/ Alcazaba (18) (Caro, Acosta y Escacena 1986).

Cabría añadir a todo ello las inferencias sacadas de algunos documentos gráficos, especialmente el grabado de G. Hoefnagle impreso en la obra Civitates Orbis Terrarum (Colonia, 1572-1617), de que nos hemos servido para la reconstrucción del Castillo en el artículo ya citado, el plano de D. José López Alegría (siglo XIX) o el estudio de los catastros municipales y viarios, pero renunciamos a analizarlos en detalle por no alargarnos demasiado, teniendo en cuenta además que su aportación al conocimiento de la ciudad antigua siempre es indirecta.

\section{CONDICIONANTES GEOGRÁFICOS Y ORÍGENES DEL ASENTAMIENTO HUMANO}

En los últimos años son varias las iniciativas que han abordado la tarea de reconstruir el paleopaisaje correspondiente a la comarca del Bajo Guadalquivir-Marismas, precisándose las aproximaciones que se venían haciendo en función de los textos clásicos y la interpretación visual y/o geológica del relieve (Gavala 1959). Tanto desde los fundamentos de la paleogeografía-geomorfología (v.gr. Ojeda 1989) como a través de proyectos geoarqueológicos (Borja 1995; Arteaga et alii 1995), la visión que hoy se puede ofrecer de las antiguas líneas de costa desde el máximo transgresivo flandriense (c. $6000 \mathrm{BP}$ ) así como la evolución interna del estuario/lago en la primitiva desembocadura del Guadalquivir, valorando la influencia sobre

8. Las referencias a la obra de J. Bellido provienen del Cap. I de la misma, pp. 1-29.

9. Aparte las ruinas del Castillo, que estudiamos pormenorizadamente en otro trabajo: Tomassetti (1997). 
ella de la actividad humana, proporciona una cada vez más sólida información espacial sobre la que situar los acontecimientos histórico-culturales.

Según las obras citadas, la costa correspondiente a la margen izquierda de las actuales marismas tendría, al menos desde el Neolítico, una delineación festoneada muy irregular, con importantes entrantes hacia tierra firme, los esteros, en cuyos márgenes se constatan tempranos establecimientos humanos que a menudo alcanzarán amplia perduración cronológica (fig. 1). En concreto para Lebrija, se ha identificado un establecimiento Neolítico Pleno-Final en el estrato I de 1986 (C/ Alcazaba) cuya importancia está aún por valorar, en relación con una construcción arquitectónica, posiblemente defensiva. Similar cronología (C-14, c. 3300 a.C.) arrojan los sedimentos marinos del muy cercano sondeo SE-115 de Arteaga et alii (1995: 112), quienes interpretan que la presión antrópica ejercida ya en tan tempranos momentos incidiría en los inicios de la colmatación de la bahía.

La morfología de la costa no sufrirá cambios importantes, manteniéndose la influencia mareal en las antiguas ensenadas atlánticas hasta al menos el I milenio a.C. (Borja 1995: 83). El inicio de la conversión en marisma de estas amplias superficies no será efectiva hasta después de la época tardorromana, de manera que la localización de Asta o Nabrissa es indicativa "de la condición marítima de sus puertos, cuando la desembocadura del Baetis no había avanzado todavía más hacia la actual línea costera" (Arteaga et alii 1995: 119 y 123; también Caro 1986-87: 65; Borja 1995: 83-84).

Semejante entorno natural, de claro carácter marítimo, envolvería desde su primera ocupación al cerro del Castillo, con una altura máxima actual de 72 m.s.n.m.. Con mayores o menores fluctuaciones del nivel de las aguas ${ }^{10}$, el paisaje permanecería estable hasta que en época turdetana la aglomeración humana vaya adquiriendo rasgos urbanos (figs. 2 y 4). La aproximación a la topografía original, en la que seguimos la interpretación de García de Jalón (1987: 9 y 22), nos muestra un cerro amesetado sobre el que se dispone, a manera de "segundo piso", otra elevación de menores dimensiones. Las aguas litorales bañarían sus escarpes formando pequeñas calas a uno y otro lado del promontorio llegándolo a convertir, en determinados momentos al menos, en una pequeña península destacada de su entorno. Visto desde el Oeste, el cerro presentaría flancos escarpados (fig. 4), pero en sus laderas sur y este se suavizaba la pendiente de manera gradual hasta alcanzar las zonas más bajas de la actual Plaza de España (fig. 3). Hoy, el relieve ha sufrido no poco por la acción de los agentes naturales y, muy especialmente, la actividad antrópica. De hecho, la meseta más baja se encuentra en gran parte desmantelada, teniéndose constancia de que fue aprovechada como cantera de arena desde mediados del siglo XV (Bellido 1985: 135). Desde la instalación de contingentes romanos en el lugar, todo el sector norte y oeste quedaría desplazado del centro de población, de manera que se ha conservado, a pesar de su constante degradación, como importantísima reserva arqueológica -lo cual ya fue advertido por García de Jalón (1987: 32, nota 1)- de manera similar a como evolucionó la ubicación de Osuna (Campos 1989: 107-110) y, tal vez, de otros enclaves cercanos al Guadalquivir (Écija, Coria del Río...).

Por el límite oriental, desde la Plaza de España, donde confluirían las aguas procedentes de las tierras de campiña más elevadas, encauzadas por arroyos cuyos lechos terminaron convirtiéndose en accesos importantes a la ciudad, por donde hoy discurren las calles Sevilla y Corredera, se formaba un curso de agua de mediana importancia, en la dirección de la actual C/ Arcos, que desde fines de la Edad Media, cuando aún su caudal obligó a construir dos puentes de madera para cruzarla, se llamaba "Arroyo Zangalabota", nombre que ha pervivido en el callejero contemporáneo (Bellido 1985: 438-439; mapa de López Alegría) (fig. 2).

10. Que han sido valoradas con cierta aproximación, y en función de muy diversos datos, por A. Caro (1989, 1991, etc.), ensayando a la vez la reconstrucción del ecosistema y la climatología reinante. 
Con la base de una geografía local como la que hemos presentado han de entenderse las hipótesis de evolución urbanística que enseguida pasamos a plantear. Nos valdremos para ello de la documentación más arriba expuesta y del análisis visual detenido de la cartografía, especialmente los planos del catastro, aunque no nos detendremos ahora en sus pormenores. Nuestra intención no va más allá de presentar un grupo de ideas que ordenen coherentemente la información conocida, ensayando un modelo dinámico de evolución urbana desde fines de época turdetana hasta la Plena Edad Media.

\section{UN OPPIDUM DE CARA AL MAR}

Si bien la primera ocupación del cerro del Castillo puede datarse, como se dijo, en el Neolítico, dilatándose la presencia humana sobre su superficie hasta el presente, el momento en que el hábitat adquiere categoría urbana se presta a la discusión. Caro (1986-87: 59 ss.) supone que esto ocurriría desde el Bronce Final pretartésico, aunque advierte de la escasez de materiales coetáneos, pareciéndole explicable por el continuismo en la ubicación del hábitat. Tejera (1979: 205; 1985: 92) adscribe al Bronce Final pleno los restos de una construcción de planta rectangular (Estrato IV de Huerto Pimentel) que pensamos pueden relacionarse con la estructura detectada en el Estrato VII de C/ Alcazaba, perteneciente al Orientalizante. De ser así, nos quedaríamos sin evidencias arquitectónicas anteriores a la presencia de materiales de importación fenicios. La cuestión aún se dificulta más si admitimos con Escacena (1985: 188) que "en Lebrija no existen de momento indicios evidentes de una ocupación estable durante el Bronce Final precolonial". No sin correr riesgos, podemos concebir el inicio de la estructura urbana, aunque no valorar sus componentes -salvo las evidencias de habitaciones rectangulares con base de mampuestos y alzado de adobes-, de modo similar a como se viene estudiando en Tejada la Vieja, donde la ocupación se iniciaría en el siglo VII a.C. (Fernández 1987: 153 ss.).

En realidad, la caracterización de la ciudad tartesia sólo cabe hacerse respecto al modelo general de su emplazamiento, similar al de tantos otros en la comarca del Bajo Guadalquivir, al modo como lo hizo Caro (1986-87: 59-61), quien recalca su estratégica ubicación respecto a su propia defensa, en un cerro destacado especie de "acrópolis" natural, y respecto a sus posibilidades de explotación portuaria y de control del eje Guadalquivir-Marismas ${ }^{11}$. El respaldo arqueológico viene proporcionado por los hallazgos casuales, tanto de importantes objetos de orfebrería ritual (los "Candelabros de Lebrija", encontrados cerca del Huerto Pimentel: Almagro 1964) como de cerámicas, siendo éstas los indicios que hacen pensar en la posible ubicación de una necrópolis orientalizante en la zona "Traseras del Castillo-Fuente de Márquez", al Suroeste del cerro (Caro 1986-87: 66); y por los correspondientes niveles en las estratigrafías comentadas (II de H. Pimentel y VI-VII de C/ Alcazaba).

Una sola evidencia nos permite identificar mínimamente el límite del espacio amurallado en los momentos finales del núcleo de población turdetana. Nos referimos a la muralla de adobes excavada en 1986 en el solar de C/ Alcazaba. La interpretación de sus excavadores es la que sigue: "Del Ibérico final o de la fase íbero-romana es una gran muralla de adobes cuadrangulares que debió servir de defensa de la acrópolis, una muralla interior ya que la principal estaba en cotas más bajas de la ladera y casi paralela a la aquí detectada" (Caro, Acosta y Escacena 1986: 169). A falta de revisarse la interpretación estratigráfica de aquella campaña, su construcción parece encajada en el estrato X, estando en uso durante el espacio cronológico en que se

11. En su esquema, Lebrija sería un centro indígena tempranamente aculturado cuyo urbanismo revelaría cierto arcaísmo, tratándose de una población muy concentrada y poco planificada en su desarrollo espacial. Admite, y es hipótesis bastante razonable, la interpretación que da Bochardt (1599-1667) sobre el topónimo Nabrissa, creyéndolo adaptación griega del semítico NAE-PRITSA, con el significado de "población junto a las aguas". J. Bochardt. Geographia Sacra, Lib. I, Cap. 34. Leiden, 1692 (3ª Ed.), citado en Caro (1991: 191), donde precisa más su interpretación (pp. 189-196). 
depositaron los materiales del XI, estrato este último desgraciadamente mal definido, con materiales ibéricos, romanos, medievales y modernos ${ }^{12}$.

Sobre su sistema constructivo -hiladas de adobes superpuestas- conviene recordar que ya el uso de este material se atestiguó en la fase orientalizante del mismo yacimiento, no siendo por tanto novedoso, como tampoco lo es en general en el mundo ibérico, donde se encuentra bien documentado (Arribas 1982: 123-129 v.gr., usándose en muros y murallas). De adobes fueron los paramentos del templo italicense de la Colina de los Palacios, fechado en la primera mitad del s. II a.C., que descansaban sobre un cimiento de guijarros reforzado con lajas de pizarra ${ }^{13}$. Los ejemplos podrían multiplicarse.

Nos interesa especialmente resaltar su ubicación sobre el plano general. La observación de las fotografías aéreas parece indicar cómo la muralla, en su desarrollo Noreste-Suroeste, se prolonga a ambos lados de los perfiles de la cuadrícula excavada. Por el Este llega a perderse en su intersección con el barranco que limita el solar por aquí. Tal vez acertamos al suponer en función de ello que la confluencia entre ambos -barranco y muralla-nos marca el límite del oppidum turdetano en su extremo suroriental, y así lo reflejamos en las figuras 3 y 6 . Así determinado el límite por la ladera del cerro opuesta a la bahía marítima, la imagen que nos queda del núcleo habitado se concreta en algo, pues se puede aventurar que, no superando una extensión máxima de 10-11 Ha, ocupaba el promontorio natural en sus zonas más elevadas hasta la cota aproximada de $40 \mathrm{~m}$ (fig. 2). Desconocemos si la meseta superior tuvo funciones de "acrópolis" ${ }^{14}$, pero es bastante seguro que la trama de calles se extendía sobre las laderas circundantes y, sin duda, por la meseta inferior, a poniente del promontorio. Semejante disposición se vería condicionada por la presencia de la bahía a este lado, siendo reflejo claro de la orientación económica prevalente de un establecimiento costero, tal como nos informan los textos clásicos. Nuestra interpretación difiere de la que se dio en la publicación de 1986, de la que se deduce que el oppidum sobrepasaba estos límites, quedando el cerramiento de adobes como una “muralla interior". La suposición de los excavadores se basaba en la creencia de que la posterior ciudad romana, cuyo límite oriental alcanza hasta la Plaza de España, se superponía en buena parte a la preexistente: lógicamente, la presencia de este nuevo recinto defensivo no podía explicarse de otra manera.

Sin forzar la objetividad de los datos, la Nabrissa turdetana queda ahora caracterizada, en cuanto a su emplazamiento, por acoplarse a las circunstancias morfológicas y ambientales del entorno natural, obligado su espacio interior a bordear las alturas del terreno, disponiendo su callejero en función de las curvas de nivel y adaptando sus límites a las escarpaduras de la topografía. Nos tienta la idea de asimilar el resultado final de estos constreñimientos al conocido en poblados levantinos del tipo Bastida de Mogente o, mejor, Puig Castellar (Arribas 1982: figs. 31 y 33).

12. Escacena (1989:458) sugiere incluso la posibilidad de haber sido erigida durante la dominación romana, aunque desconocemos en qué basa tal cronología, que le sirve para constatar la pervivencia de la técnica constructiva con adobes, indígena, a pesar de la completa romanización de la Turdetania que nos transmite Estrabón en su Geografía.

13. En los niveles 10-11 (estrato IX) de C/ Alcazaba se constató la presencia de una laja de pizarra vertical que tal vez pudo estar en conexión con la estructura de la propia muralla que estudiamos. En tal caso, convendría precisar la relación que pudo existir entre ambas por si ha lugar relacionar el sistema con el del mencionado templo de Itálica. Al menos cronológicamente no es aventurado suponer que así fuera. Vid. León (1977-78: 144).

14. Una reciente intervención de urgencia en el Castillo, dirigida por los arqueólogos C. A. Quirós y J. M. Rodrigo, ha detectado los fundamentos de una "torre" turdetana en la zona más alta, provisionalmente fechada en los siglos IV-III a.C. Agradecemos la información a los directores de la excavación. Por el momento, no nos atrevemos a sacar conclusiones de este dato. 


\section{UNA CIUDAD ROMANA YUXTAPUESTA}

Puede pensarse que un lienzo de muralla de adobes sobre cuya datación persisten ciertas dudas es indicio inconsistente para fundamentar nuestra hipótesis. Sin embargo, otras ideas nos ayudarán a fortalecerla, esta vez referidas al nuevo núcleo urbano surgido inmediatamente tras la llegada romana. Carecemos de datos para fechar con exactitud la primera presencia de Roma en Nabrissa. Ciertamente su venida pudo acaecer en algún momento en torno a mediados del siglo I a.C., cuando las legiones de César llevan a cabo sus campañas de conquista como parte de la Guerra Civil de finales de la República. Con él se ha querido relacionar el sobrenombre Veneria que, desde estas fechas, adquiriría la población, sin por ello perder su antigua denominación, hecho frecuente en el Occidente romano y, desde luego, en la Bética ${ }^{15}$. Existen, sin embargo, cerámicas campanienses tipo B que sugieren una fecha más antigua, s. II a.C., pero su correcta valoración no podrá hacerse hasta que poseamos secuencias cronológicas fiables, no siendo de utilidad los estratos I de H. Pimentel ni XI-XII de C/ Alcazaba. Tampoco avanzamos nada discutiendo sobre el estatus jurídico de la fundación romana. Admitimos, con las debidas reservas, la afirmación de Tovar (1974: 147) de tratarse de un oppidum Latinorum o ciuium Romanorum, descartando que se constituyese como municipio o colonia ${ }^{16}$.

La localización sobre el plano de la nueva Nabrissa se nos presenta más fácil. Poseemos la descripción que López-Quiroga hizo de las murallas y puertas, fundamental para interpretar los límites de la Veneria romana. Dos advertencias se hacen necesarias: primero, que su itinerario incluiría las remodelaciones postromanas del recinto amurallado, especialmente las efectuadas durante el dominio de los almohades entre los siglos XII y XIII, que, según entendemos, ampliaron el perímetro preexistente; en segundo lugar, que la reconstitución que ensayemos debe valer a partir del levantamiento de la muralla romana en una fecha inconcreta, tal vez no anterior al siglo II d.C. si hemos de admitir el esquema teórico que hace depender la fortificación de las ciudades béticas de la inestabilidad política producida por las invasiones de maurio la crisis general del s. III. Aún así, gran parte del espacio urbanizado quedaría fuera del nuevo cinturón murario ${ }^{17}$, de manera que nuestra valoración sigue siendo bastante parcial. La figura 6 presenta por tanto un esquema indicativo de los distintos emplazamientos de los centros turdetano y romano, rodeado el segundo por unas murallas posteriores al origen del asentamiento republicano pero que reservarían en su interior lo fundamental del entramado urbano primitivo. La red viaria representada es meramente teórica, al igual que en la figura 7.

La formación de dípolis, ciudades dobles o yuxtapuestas, como efecto directo de la conquista romana, sea durante la República o ya en el Alto Imperio, ha sido advertido en todas las provincias occidentales. Habitualmente, los romanos optan por no aprovechar los oppida indígenas y construir sus nuevos asentamientos, cualquiera que fuese su estatuto jurídico, ex novo, a menudo en las proximidades del poblado autóctono, pero en "tierra de nadie", elección sobre la que influirían motivos políticos de seguridad además de las necesidades constructivas de su peculiar planificación (Kolb 1992: 181, 187, 224). Se dieron desde luego casos de superposición, pero predomina la duplicación: en la Galia mediterránea (Narbona) (Grimal

15. Que César pasara o no por Lebrija tras la batalla de Munda (45 a.C.), como quiere Bellido (1985: 15), opinión contraria a la de Caro (1991: 39), queda fuera de nuestro actual interés. El cognomen Veneria nos lo transmite Plinio (Nat. Hist. III, 11: At inter aestuaria Baetis oppida Nabrissa, cognomine Veneria...). Entendemos que el acto de imponer "apellido" latino a una ciudad indígena forma parte de la política romanizadora de los conquistadores, pero a la vez de ello puede inferirse que la pervivencia de ambas denominaciones es el reflejo de la permanencia de dos poblaciones distintas.

16. Las diversas opiniones sobre la cuestión las resume Caro (1991: 38-39).

17. “les remparts du Bas-Empire n'entourent jamais que le coeur de l’agglomération du Haut-Empire (...) destinés non à abriter la population civile qui continue à vivre partiellement hors les murs, mais à protéger la garnison et les services administratifs (...) en fait elles posséderaient des quartiers extra muros". Clavel-Levêque et Levêque (1971: 62-63). Una cronología en torno a los siglos II-III d.C., aunque no exclusiva, propone Jiménez (1977: 236-237) para las defensas de Niebla, Tejada la Nueva, Gerena, Itálica, Alcalá del Río y Carmona. 
1991: 7-8); en Aquitania, a ambos lados del Garona (Burdeos, Limoges, Cahors, Agen, Périgueux...) (Bost 1982: 62-63); en Edetania (Lloma de Manoll y Castellet de Bernabé, de Lliria) (Bernabeu et alii 1985-87: 150-151), y en general en todo el Levante valenciano desde el s. III a.C. (Morote 1984:91); en las fundaciones augústeas del Noroeste ibérico (Astorga, Lugo y Braga) (Tranoy 1982: 131)... Por supuesto, en la Bética, bien documentado en Osuna (Campos 1989: 107-110; Corzo 1977: 10) o en la misma Itálica, en opinión de R. Corzo, estableciéndose el foro de la Vetus Urbs en la vaguada entre el asentamiento indígena (Cerro de San Antonio) y el primitivo campamento (Cerro de los Palacios) (Vid. León 1985: 19).

El sistema de desdoblamiento se observa como un progresivo deslizamiento de las instalaciones urbanas desde las zonas más altas hacia otras medias o bajas respecto a la ubicación original ${ }^{18}$. A veces, la traslación de la ciudad conlleva el abandono del recinto anterior (Narbona, Osuna, ejemplos de Edetania), pero también se conocen casos de fusión de los dos centros (como ocurre en Itálica, en torno al foro). Se producen así verdaderas fundaciones de nueva planta que prefieren alojarse en laderas de poca pendiente o zonas llanas, huyendo de los relieves accidentados. Conocer las ventajas de esta estrategia obligaría a hacer un análisis particular de cada caso. Posiblemente facilitaba la finalidad aculturadora de las nuevas poblaciones en tanto permite exportar en su integridad un nuevo orden urbano, con todo lo que ello conlleva, verdadero escaparate de las "ventajas" de la administración de Roma. Los ingenieros romanos, además, preferirían aplicar su modelo urbanístico de la manera más fácil, evitando los problemas que plantea tanto la adaptación de un poblado anterior -de trazado geomórfico, organizado en su interior de modo muy diferente- como una naturaleza abrupta.

Concretando, en Lebrija observamos un claro desplazamiento del centro de gravedad urbano hacia el Este por la ladera que baja del Castillo hacia la Plaza, más allá de los límites que antes establecimos para el final de la fase turdetana. Que ambos núcleos fueron independientes se infiere de dos hechos: a) de las cuatro puertas establecidas por López-Quiroga, tres son perfectamente ubicables (puntos 1, 2 y 3 de la fig. 5), pero la más occidental, llamada "de Jerez", aún se encuentra por identificar, sin llegar a ser satisfactoria ninguna de las propuestas que conocemos (en los alrededores del Callejón del Rastro); la dificultad de su situación debe responder a una intensa alteración del callejero, en dos sentidos: la puerta original debió hallarse más o menos enfrentada a la de Sevilla (fig. $5, \mathrm{n}^{\circ}$ 2) en la línea de la C/ Antonio de Nebrija, cuyo actual trazado a cordel fosiliza el primitivo del decumano; la interpretación habitual de la planta antigua ha impedido a los investigadores suponerla en este sector de la ciudad. Por otra parte, las reestructuraciones medievales conllevaron la articulación, hasta entonces no ensayada, entre la ciudad romana y la zona alta del Castillo, entonces fortificada como Alcazaba, levantándose un lienzo de muralla que acogiera el espacio transicional entre ambos. En dicho lienzo se practicarían sus respectivos accesos (al menos uno; vid. fig. 7), de los que tampoco ha pervivido resto alguno, aunque tal vez López-Quiroga llegó a tener noticia de ellos. La Puerta de Jerez, en nuestra opinión, no debe ser identificada con uno de los accesos a Nabrissa-Veneria, sino a la villa medieval, o, si lo preferimos, hemos de llamar así a la salida del decumano por el lado de poniente ${ }^{19}$. Y b) la recuperación medieval de la superficie entre "acrópolis" y ciudad romana nunca llegó a ser efectiva, o al menos el uso al que se destinó no suponía su completa edificación (tal vez fue musara de la medina, y no la Plaza de España, como interpreta García de Jalón; fig. 7), habiéndose conservado como espacio abierto hasta el presente siglo; es más, la estratigrafía de C/ Alcazaba, a pesar de las dificultades de interpretación de su estrato XII, apenas ha proporcionado material romano de ninguna época, y entre los restos recuperados del barrio de Cantarranas (Tomassetti 1996) es igualmente escaso: suponer ambas zonas como extramuros es hipótesis muy razonable.

18. En los citados yacimientos de Lliria se han estudiado hasta tres fases sucesivas, de arriba a abajo: Ibérico Pleno, Ibérico Final y Romano, éste último muy cerca del precedente.

19. Todos los nombres de puertas, salvo la de Santiago -que conducía a la marisma-, hacen referencia a la dirección de los principales caminos que se iniciaban en ellas. 
No podemos decidir por el momento si la yuxtaposición de la nueva ciudad llevó aparejado el abandono de la preexistente pues son aún muchos los interrogantes que esperan ser resueltos, aunque no descartamos que así fuera. Tampoco sabríamos responder a la cuestión de si la zona más alta del cerro del Castillo estuvo en uso durante los siglos de dominación romana ${ }^{20}$. Lo único indudable es que entre sus escasas ruinas no existe ningún indicio datable más allá del siglo XII d.C. (Tomassetti 1997). En todo caso, desde fines de la República, el oppidum Nabrissa se convierte en una ciudad doble, estableciéndose los pobladores recién llegados en la ladera oriental, separados varias decenas de metros de los habitantes autóctonos, sobre una superficie de suave pendiente en la ribera de una mediana corriente de agua (el Arroyo Zangalabota, vid. fig. 2). La elección del lugar entra dentro de lo habitual en el caso de fundaciones romanas en el occidente europeo y puede explicarse, mejor que peor, ateniéndonos a las líneas básicas del catastro actual.

Respecto a la distribución de los principales elementos urbanos que compusieron el esquema de la ciudad, haremos algunas consideraciones:

Las calles. Con fiabilidad sólo conocemos el trazado de las dos vías principales, cardo y decumano. Ya fueron identificadas antes por Caro (1981) y García de Jalón (1987) y tan sólo cabe hacer una precisión más. El cardo seguía la dirección de las actuales calles J. Sánchez de Alva y Empedrada, entre las puertas de Santiago y Rota (fig. 5, $n^{\circ} 1$ y 3). La interpretación del decumano fluctuaba entre la mencionada C/ Antonio de Nebrija y la unión de Ignacio Halcón-Plaza Rector Merina-Condesa de Lebrija, o se admitía la posibilidad de un doble decumano en forma de huso. Como hemos dicho, la controversia la creemos resuelta al conceder que seguiría el trazado de la primera, prolongando el eje que parte de la Puerta de Sevilla (fig. $5, n^{\circ} 2$ ) hacia la hoy desconocida de Jerez. La actual distribución de manzanas en el casco histórico de Lebrija traduce mínimamente aún la primitiva disposición de ínsulas rectangulares, aunque invadidas muchas de las vías secundarias que las delimitaban.

El foro. Es bien sabido cómo entre los principios generales del urbanismo romano el foro destaca como la pieza maestra en torno a la que gira la vida ciudadana. Su papel quizá ha sido exagerado al concebírselo, en cuanto a su situación, demasiado en función de conceptos geométricos un tanto idealizados. La realidad permitía e incluso obligaba a saltarse la norma de centralidad establecida por los tratados de arquitectura, ya que las condiciones específicas de cada localidad no siempre aconsejaban ubicarlo según tales preceptos (Grimal 1991: 51; Kolb 1991: 196). Para Lebrija se han manejado dos hipótesis, ambas originadas en la Carta Arqueológica de Caro (1981): la Plaza Rector Merina, frente a la Parroquia de Santa María de la Oliva, y el sector ocupado por el Convento de Monjas Concepcionistas, en la C/ Antonio de Nebrija (o en la manzana frontera al mismo, puntos 6 y $12 \mathrm{de} \mathrm{la} \mathrm{fig.} \mathrm{5).} \mathrm{Nos} \mathrm{cuesta} \mathrm{optar} \mathrm{por} \mathrm{una} \mathrm{u} \mathrm{otra} \mathrm{solución} \mathrm{a} \mathrm{tenor}$ de la poca información de que disponemos, pero creemos algo más acertada la primera de las hipótesis si hacemos el siguiente razonamiento: si el espacio abierto que ha permanecido en la Plaza Rector Merina desde que fuese foro de la ciudad se encuentra menos centrado en el plano que proponemos, no tuvo por qué ser así respecto a la máxima extensión urbana antes de levantarse la muralla que la limitó a principios del Bajo Imperio. Por otro lado, que en él no se crucen cardo y decumano nada indica, pues en época imperial la circulación viaria procuraba evitarlos, llegando a quedar en casos aislados por cuatro calles que los bordeaban (Jiménez 1987: 175). La misma disposición de esta plaza desde fines de la Edad Media, donde se enfrentan Iglesia y Cabildo municipal, podría estar traduciendo un esquema axial simétrico muy frecuente en los foros imperiales, donde además el templo solía "dominar el conjunto monumental desde una posición elevada con respecto al nivel de la plaza" (Jiménez 1987: 174), como es exactamente el caso de la Iglesia de la Oliva ${ }^{21}$.

20. A la espera del informe de la excavación citada.

21. Aunque su actual arquitectura no se cree más antigua del siglo XIII, son diversas las opiniones que quieren ver en ella una anterior mezquita, sinagoga o incluso basílica visigoda (sobre su Puerta del Sol se encuentra una lápida del s. VI que provendría de la necrópolis adyacente). La transformación de templos paganos en iglesias cristianas es habitual y se conocen algunos casos muy significativos en Carmona y Écija (García 1977-78: 314-316). 
La muralla. Nada sabemos sobre que la nueva ciudad se rodeara de defensas antes de las fechas que se indicaron más arriba. La disposición que presentamos en la figura 6 tiene mucho de hipotético y nuestro conocimiento se reduce a lo siguiente: es clara su presencia entre las puertas de Sevilla y Rota (fig. $5, \mathrm{n}^{\circ} 2$ y 3), por el interior de las manzanas actuales, que crecieron apoyadas sobre ella cuando se amplía la villa tras su repoblación, a lo largo de la Baja Edad Media. Este trazado curvo continuaba hacia el Norte, buscando la puerta de Santiago (punto 1 de la fig. 5), pero el sistema empleado en este tramo es bien diferente, pues se corta transversalmente el espolón natural de la Peña, a modo de foso, segregando un cabezo de perfiles abarrancados cuyas caras exteriores completan el sistema defensivo (figs. 2-donde se reconstruye el espolóny 3 ; fig. $5, \mathbf{n}^{\circ} 11$ ). Esta obra de ingeniería se ha venido atribuyendo a la población turdetana o anterior (Caro 1986-87: 61-62), más tarde aprovechada por los romanos, pero dentro de nuestro esquema de ciudad geminada carece de fundamento tan alta cronología. El foso dio origen más tarde a la $\mathrm{C} / \mathrm{Cataño}$. Desde la Puerta de Santiago, en dirección Oeste, debía seguir una línea sensiblemente recta que pasaba tras la Iglesia de la Oliva, donde durante los siglos XV-XVI existía el Callejón del Carnero (fig. 8), continuación de la C/ Adán y Eva, en cuya esquina permanece aún un paño del muro, si bien su fábrica de mampuestos con intercalación de verdugadas horizontales de ladrillo puede deberse a momentos posteriores (fig. $5, \mathrm{n}^{\circ} 13$ ). La cara occidental del recinto se encontraría a una altura indefinida entre las líneas de las calles Sinagoga y Morón. El reducido espacio contenido al interior, en torno a $6 \mathrm{Ha}$, concentraba en su superficie los servicios fundamentales de la administración ciudadana y el culto religioso (foro, capitolio, basílica, macellum...) ${ }^{22}$.

Las puertas. No repetiremos su situación, sobre lo que ya se ha insistido. La llamada de Sevilla, cuyas ruinas pervivieron hasta 1841 (Bellido 1985: 9), era monumental, provista de tres arcos, el del centro mayor que los laterales, esquema arquitectónico raro antes del s. II d.C. (Robertson 1988: 270). La de Santiago queda descrita por López-Quiroga: "para cerrar el espacio que había entre el barranco y la otra altura había siete arcos, seis de ellos ciegos y uno de enmedio descubierto, que servía de puerta" (Bellido 1985: 7-8). El ser tan numerosos los arcos, para una simple puerta, y encontrarse cegados la mayoría nos induce a pensar que se tratase de un acueducto reaprovechado en el momento de proteger apresuradamente la ciudad con un cinturón murario. La presencia de acueductos no es inhabitual en los centros urbanos, por pequeños que fuesen (Grimal 1991: 86), y su reutilización en el sentido que apuntamos se ha constatado en otros lugares ${ }^{23}$. A la vez, sería una prueba indirecta de la premura con que se acometieron las obras de defensa, indicio de una etapa de inestabilidad política como la sugerida para la erección de la muralla, e indicio también de desarrollarse ésta por el interior de la ciudad imperial sin abarcar toda su extensión.

Las necrópolis. Conocemos la situación de un cementerio tardío, posterior al s. III d.C., encajado en el foso de la C/Cataño, casualmente descubierto durante la realización de obras de alcantarillado a principios de los años 80 (fig. $5, \mathrm{n}^{\circ} 11$; fig. 6). Su hallazgo no dio lugar a ninguna actividad arqueológica. Lo visto por nosotros fueron un par de filas de enterramientos de inhumación, excavados en el suelo del foso preexistente y cubiertos con tégulas dispuestas a dos aguas. No nos consta que las tumbas proporcionaran ninguna clase de ajuar. Bordeando las principales vías de acceso a la población, calles Sevilla y Corredera, sobre todo en esta última, se erigieron construcciones funerarias, de las cuales provienen algunas inscripciones con la fórmula D.M.S.

22. A. Blanchet (1907) nos presenta numerosos ejemplos de ciudades francesas cuya evolución condicionada por las murallas romanas ha dado lugar a esquemas muy similares. La norma es que, cuando el crecimiento medieval y moderno ya las había rebasado, sigan manteniéndose en el sector que delimitan los principales edificios públicos: iglesias, ayuntamientos, etc. Los planos de Andernach, Meaux, Noyon, Senlis, entre otras, recuerdan vivamente al de Lebrija.

23. En Bourges, las arcadas de la sala del palacio del duque Jean; en la misma Roma, al restaurar las defensas c. 272 d.C., cuando las murallas de Aureliano aprovechan el cuartel de los pretorianos, un anfiteatro (también en Périgueux), tumbas y las arquerías de los acueductos del Esquilino (Blanchet 1907: 254; Grimal 1991: 93). 


\section{UNA VILLA DE ESPALDAS A LA MARISMA}

La orientación de la vieja Lebrija, orientación no sólo en sentido espacial sino también socioeconómico, volverá a verse alterada tras el esplendor, y la decadencia, de su pasado romano. La dificultad de estudiar esta otra transformación estriba en la escasez o absoluta carencia, según el momento cronológico, de informaciones de todo tipo para acercarnos a su conocimiento entre lo tardorromano, periodo que en sí mismo es parco en noticias, y la Plena Edad Media. La investigación aún podrá precisar algunos extremos por ahora desconocidos a través de la consulta y depurada interpretación de documentos escritos no tenidos en cuenta, pero será la arqueología quien proporcione la mayor parte de las respuestas.

A partir del siglo IV d.C., como antes se apuntó, se acelera el proceso de colmatación sedimentaria del antiguo lago que acentúa la degradación de su carácter estuarino en una constante evolución natural influida cada vez más por la acción antrópica en su entorno próximo, con especial incidencia desde la Edad Media (Arteaga et alii 1995: 116; Borja 1995: 84). El progresivo alejamiento de las orillas y la desecación de amplias superficies, que pasan a ser tierras de marisma inundable surcadas por caños y lucios, debió dejarse sentir con fuerza en las economías de las poblaciones circundantes, las cuales perderían interés por el aprovechamiento de sus recursos naturales, bien diferentes a los que proporcionaban las tranquilas aguas interiores del estuario, y ahora de segunda importancia, tanto en sí mismas como por las transformaciones que la romanización conllevó en la explotación agropecuaria de las tierras de campiña.

La respuesta del núcleo urbano a estos acontecimientos, aunque no sólo a ellos, se traduce en un progresivo deslizamiento que traslada su centro geográfico en dirección opuesta a las bajas tierras inundables, no siendo ajena en su desplazamiento a los inconvenientes que para la salud de sus habitantes suponía la vecindad con ellas ${ }^{24}$.

Cuando recuperamos la constancia de que Lebrija vuelve a desempeñar un cierto papel en el acontecer histórico, pasada una larga etapa de oscuridad que casi nos oculta su existencia, sobre todo para los siglos altomedievales, hasta la presencia de soldados almohades acuartelados en una alcazaba erigida sobre el cerro del Castillo, parece que la población ha perdido su vocación marítima. El remozado aspecto de su organización urbana, del que ya hemos hecho algún breve comentario, pero en el que no nos extenderemos en esta ocasión, conserva la imagen de la urbe romana, pero ha sufrido importantes modificaciones que afectan poco a su extensión y bastante al sistema de defensa. La muralla, en su cara septentrional, invade nuevos espacios hacia el Norte (fig. $5, n^{\circ}$ 9). En el nuevo lienzo se practica un acceso del que apenas se intuye hoy su trazado en recodo, discurriendo por la Cuesta del Guineo, flanqueado por torres (fig. 5, $\mathrm{n}^{\circ}$ 14-15). La planta básica de las ruinas del Castillo tuvieron en los alarifes musulmanes su origen, aunque por desgracia sólo quedan en pie una docena de paramentos bastante modificados tras la Reconquista (Tomassetti 1997). Medina y Alcazaba se unen también con murallas, aunque los replanteos propuestos (Caro 1981; García de Jalón 1987) han de ser confirmados en el futuro. Al menos en el nuevo tramo del lado Sur, a tenor de la interpretación que estamos llevando a cabo de ciertos restos arquitectónicos de la excavación de C/ Alcazaba, pudo haber consistido en un sistema de muro y antemuro precedido por un escueto foso (muros 2,3 y 4 del corte A) ${ }^{25}$. Con suave dirección noroeste seguiría hasta el corte IA de 1987, desde donde tal vez encaraba hacia la torre conservada cerca de la fortaleza (fig. $5, n^{\circ} 16$ y 18). Extramuros del lado norte y muy cerca de la puerta en recodo antes reseñada pudo localizarse la necrópolis o maqbara (fig. $5, \mathrm{n}^{\circ} 10$ ), a juzgar

24. No debe extrañar este movimiento reflejo si no olvidamos que, como bien expresó Chueca (1982: 27 y 31), "la ciudad, en última y radical instancia, es un ser histórico" (...) "nunca independiente de las etapas por las que pasó en su evolución: es actualización de ellas y su proyección hacia el porvenir".

25. Aunque la difícil interpretación del estrato XII parece sugerir que estas construcciones no sean anteriores a la ocupación cristiana. El futuro estudio de detalle de los materiales cerámicos contenidos en los "pozos", y su relación estratigráfica con los paramentos murarios conservados debe desvelar su correcta adscripción cronológica. 
por los restos arqueológicos y antropológicos allí aparecidos (Tomassetti 1996). La musara, ya se dijo, se encontraría ante la puerta de Sevilla (García de Jalón 1987) o, como pensamos, en el espacio que quedó habilitado al Oeste de la aglomeración romana, ahora dentro del perímetro defensivo.

Los pobladores llegados tras los acontecimientos bélicos de la Reconquista modificarían levemente la planta, si bien desde fines del siglo XV e inicios de la Edad Moderna se habilitarían nuevos barrios y calles bordeando los caminos inmediatos, aparte las reformas interiores para alojar a las distintas instituciones municipales (fig. 8). El crecimiento futuro prescinde, sin embargo, de trastocar demasiado lo ya construido, extendiéndose por terrenos no urbanizados, hacia el Sur y el Este, a manera de "mancha de aceite", hasta que el planeamiento contemporáneo reorganiza, ordena y clasifica el modelo urbanístico en virtud de conceptos actuales.

\section{BIBLIOGRAFÍA}

ALMAGRO, M. (1964): Los Thymateria llamados "Candelabros de Lebrija". T.P. XIII. Madrid.

ARRIBAS, A. (1982): Los Iberos. Barcelona.

ARTEAGA, O. et alii (1995): "El problema del 'Lacus Ligustinus'. Investigaciones geoarqueológicas en torno a las Marismas del Bajo Guadalquivir”. Tartessos 25 años después 1968-1993. Jerez de la Frontera, pp. 99-135.

BELLIDO, J. (1945, 71 y 85): La Patria de Nebrija. Noticia Histórica. Madrid.

BENDALA, M. (1971): "Dos fragmentos de sarcófagos paleocristianos". Habis 2: 280-281.

BERNABEU, J. BONET, H. y MATA, C. (1985-1987): "Hipótesis sobre la organización del territorio edetano en época ibérica plena: el ejemplo del territorio de Edeta/Lliria". I Jornadas sobre Mundo Ibérico. Jaén, pp. 137-155.

BLANCHET, A. (1907): Les enceintes romaines de la Gaule. Paris.

BORJA, F. (1995): "Paleogeografía de las costas atlánticas de Andalucía durante el Holoceno Medio-Superior. Prehistoria Reciente, Protohistoria y Fases Históricas". Tartessos 25 años después 1968-1993. Jerez de la Frontera, pp. 73-97.

BOST, J.-P. (1982): "Specifité des villes et effets de l'urbanisation dans l'Aquitanie augustéenne". P.A. Fevrier et Ph. Leveau (eds.) Villes et campagnes dans l'Empire Romaine, pp. 61-76.

CAMPOS, J.M. (1989): “Análisis de la evolución espacial y urbana de Urso”. J. González (ed.) Estudios sobre Urso. Colonia Iulia Genetiva. Sevilla, pp. 99-111.

CARO, A. (1981): La Carta Arqueológica de Lebrija. Univ. de Sevilla, inédita.

— (1986-87): "Nabrissa (Lebrija, Sevilla). Los orígenes del núcleo urbano". Anales de la Universidad de Cádiz III-IV: 55-70.

_ (1989): "Consideraciones sobre el Bronce Antiguo y Pleno en el Bajo Guadalquivir". M.E. Aubet (ed.). Tartessos. Arqueología protohistórica del Bajo Guadalquivir. Barcelona, pp. 85-120. (1991): Lebrija, la ciudad y su entorno, I (Prehistoria y Protohistoria). Sevilla.

CARO, A. ACOSTA, P. y ESCACENA, J.L. (1986): "Informe sobre la prospección arqueológica con sondeo estratigráfico en el solar de la calle Alcazaba (Lebrija, Sevilla)”. AAA'86/III: 168-174.

CARO, A. ACOSTA, P. y TOMASSETTI, J.M. (e.p.): "Informe preliminar sobre el estudio de materiales del solar de la calle Alcazaba, de Lebrija (Sevilla)". Anuario Andaluz de Arqueología.

CARO, A. y TOMASSETTI, J.M. (1997): Antonio de Nebrija y la Bética (sobre arqueología y paleogeografía del Bajo Guadalquivir). Madrid.

CHUECA, F. (1982): Breve Historia del Urbanismo. Madrid. 
CLAVEL-LEVÊQUE, M. et LEVÊQUE, P. (1971): Villes et structures urbaines dans l'Occident Romain. Paris.

CORZO, R. (1977): Osuna de Pompeyo a César. Excavaciones en la muralla republicana. Univ. de Sevilla, Anales de la Univ. Hispalense, Serie: Filosofía y Letras, $n^{\circ} 37$.

ESCACENA, J.L. (1989): "Los turdetanos o la recuperación de la identidad perdida". M.E. Aubet (ed.). Tartessos. Arqueología protohistórica del Bajo Guadalquivir. Barcelona, pp. 433-476.

— (1995): "La etapa precolonial de Tartessos. Reflexiones sobre el «Bronce» que nunca existió". Tartessos 25 años después 1968-1993. Jerez de la frontera, pp. 179-214.

ESTEVE, M. (1961): “Ídolo cilíndrico de mármol hallado en Lebrija (Sevilla)". A.E.A. XXXIX: 161-163. FERNÁNDEZ JURADO, J. (1987): Tejada la Vieja: una ciudad protohistórica. Huelva Arqueológica, IX.

Huelva.

FERNÁNDEZ NARANJO, M.J. (1996): Movilidad y estancamiento: la población de Lebrija durante el siglo XVIII. Sevilla.

GARCÍA de JALÓN, A. (1987): Diagnóstico previo del Conjunto Histórico Artístico de Lebrija. Sevilla.

GARCÍA MORENO, L.A. (1977-78): "La cristianización de la topografía de las ciudades de la Península Ibérica durante la Antigüedad tardía". Archivo Español de Arqueología, 50-51: 311-321.

GAVALA, J. (1959): Geología de la Costa y Bahía de Cádiz. Madrid.

GONZÁLEZ, J. (1982): "Dos epígrafes cristianos de Lebrija (Sevilla)". Homenaje al Profesor Hernández Diaz. Sevilla, pp. 65-71.

GRIMAL, P. (1991): Las Ciudades Romanas. Barcelona.

HUECAS, J.M. (e.p.): "Informe preliminar de la intervención arqueológica de urgencia en el Hospital de la Misericordia de Lebrija (Sevilla)". Anuario Andaluz de Arqueología.

JIMÉNEZ, A. (1977): “Arquitectura romana de la Bética I. Introducción al estudio de lăs fortificaciones”. Segovia y la Arqueología Romana, pp. 223-238.

JIMÉNEZ SALVADOR, J.L. (1987): "Los modelos constructivos en la arquitectura forense de la Península Ibérica". Los Foros Romanos de las Provincias Occidentales, pp. 173-177.

KOLB, F. (1992): La Ciudad en la Antigüedad. Madrid.

LEÓN, M.P. (1977-78): "Notas sobre técnica edilicia en Itálica". A.Esp.A. 50-51: 143-163. (1985): "Itálica. Problemática de la superposición de Santiponce al yacimiento". Arqueología de las ciudades modernas superpuestas a las antiguas. Zaragoza, pp. 213-230.

LÓPEZ-QUIROGA, R. (1901): "Recuerdos Históricos”. El Látigo, nº 1 (Agosto). Lebrija.

MOROTE, G. (1984): "La cultura ibérica: síntesis histórica". Varia III: 61-113.

OJEDA, J. (1989): "La dinámica litoral reciente de la costa occidental de Andalucía" El Cuaternario en Andalucía Occidental. AEQUA Monografías, 1: 123-132.

PONSICH, M. (1991): Implantation rurale antique sur le Bas-Guadalquivir. Tome IV. Collection de la Casa de Velázquez, 33. Archéologie, XVI.

PULIDO, M. (1992): Lebrija entre dos siglos (1874-1936). Sevilla.

RECIO, A. (1979): "Baetica paleocristiana y visigoda: la antigua Nebrissa, hoy Lebrija (Sevilla)". Rivista di Archeologia Cristiana, n ${ }^{\circ}$ 1-2: 41-88.

ROBERTSON, D.S. (1988): Arquitectura Griega y Romana. Madrid.

TALEGO, F. (1996): Entre el trabajo y los subsidios del estado: los jornaleros de Lebrija. Sevilla.

TEJERA, A. (1979): "Huerto Pimentel (Lebrija, Sevilla): un poblado del Bronce Medio y Final en la Marisma del Guadalquivir". XV C.N.A., vol. I: 203-210.

TEJERA, A. (1985): "Excavaciones arqueológicas en el Huerto Pimentel (Lebrija, Sevilla)". N.A.H., 26: 88-16. 
TOMASSETTI, J.M. (inédito, 1994): Proyecto General de Investigación Arqueológica "Arqueología Urbana en Lebrija (Sevilla): 1995-2000". Consejería de Cultura de la Junta de Andalucía.

TOMASSETTI, J.M. (1996): “Contribución al estudio urbanístico de la Lebrija Antigua y Medieval. Los hallazgos del Barrio de Cantarranas". Estudios de Historia y Arqueología Medievales, XI: 453-480.

TOMASSETTI, J.M. (1997): "El Castillo de Lebrija (Sevilla): un primer ejercicio de interpretación históricoarqueológica". I Congreso Internacional sobre Fortificaciones en Al-Andalus. Algeciras, 1996.

TOMASSETTI, J.M. y CARO, A. (inédito, 1998) Normativa de Protección del Patrimonio Arqueológico. Plan General de Ordenación Urbana de Lebrija. Delegación de Urbanismo del Ayuntamiento de Lebrija. TORRES-BALBÁS, L. (1983): "Las puertas en recodo en la arquitectura militar hispano-musulmana". Obra Dispersa, I. Al-Andalus. Crónica de la España Musulmana, 7. Crónica XLVII (1960, XXV, 2): 122-150.

TORRES-BALBÁS, L. (1985): Ciudades Hispano-Musulmanas. Madrid.

TOVAR, A. (1974): Iberische Landeskunde, I (Baetica). Baden-Baden.

TRANOY, A. (1982): "Agglomerations indigènes et villes augustéennes dans le Nord-Ouest Ibérique". P.A. Fevrier et Ph. Leveau (eds.) Villes et campagnes dans l'Empire Romaine, pp. 125-137. 


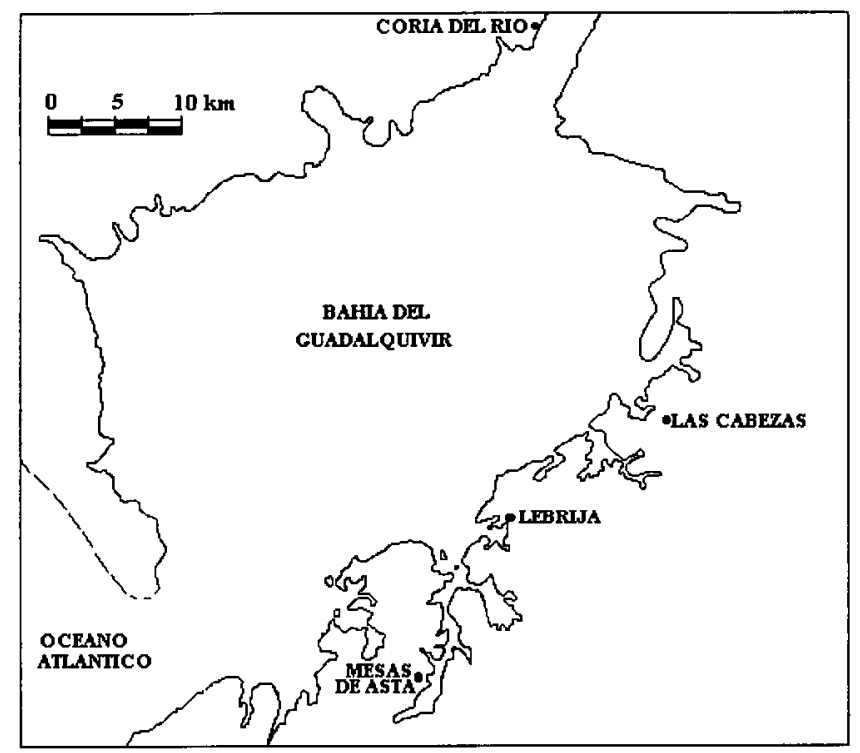

Figura 1- Línea de costa hacia 6000 BP (según Arteaga et alii 1995).

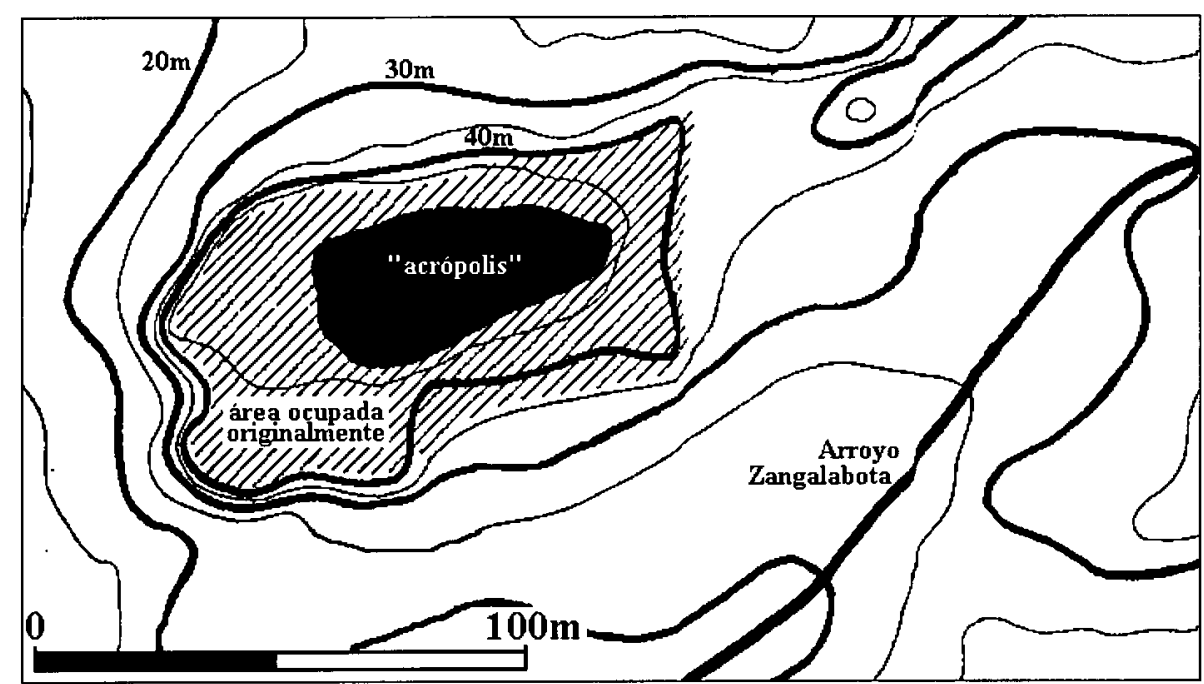

Figura 2. Aproximación a la topografía antigua (según García de Jalón 1987). 


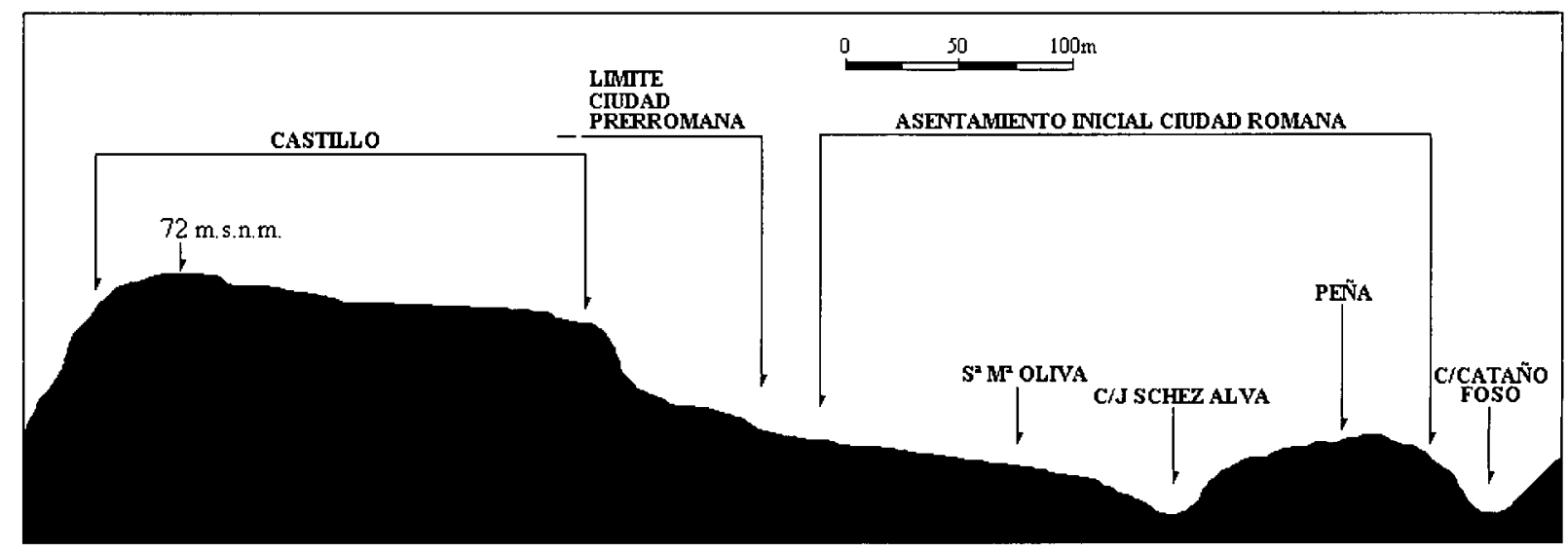

Figura 3. Perfil topográfico actual NW-SE.

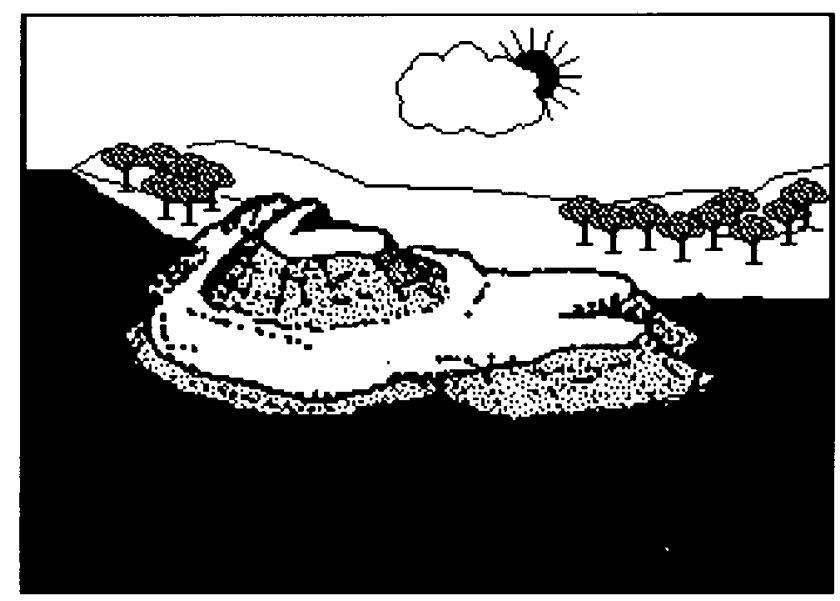

Figura 4. Aproximación al paleopaisaje original (según García de Jalón 1987). 


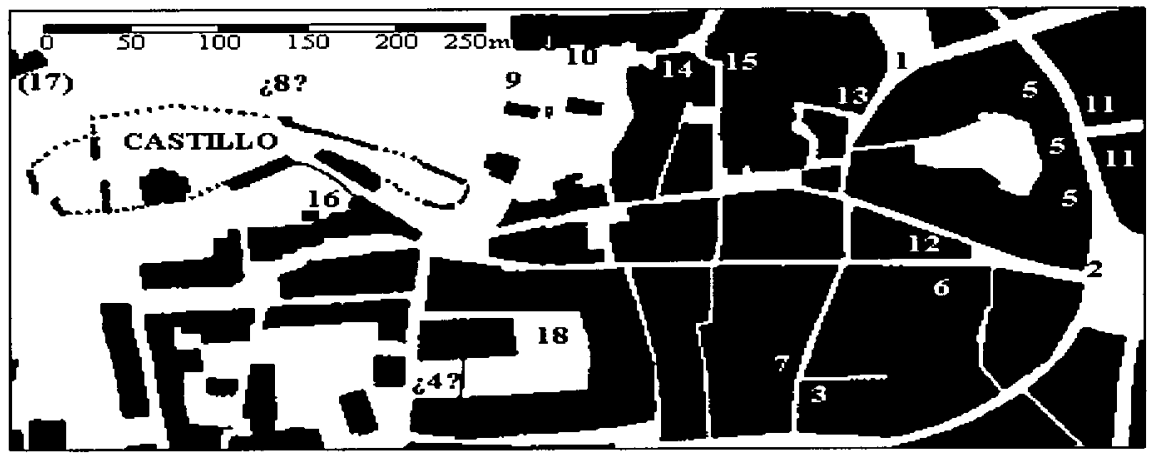

Figura 5. Localización de restos arqueológicos.

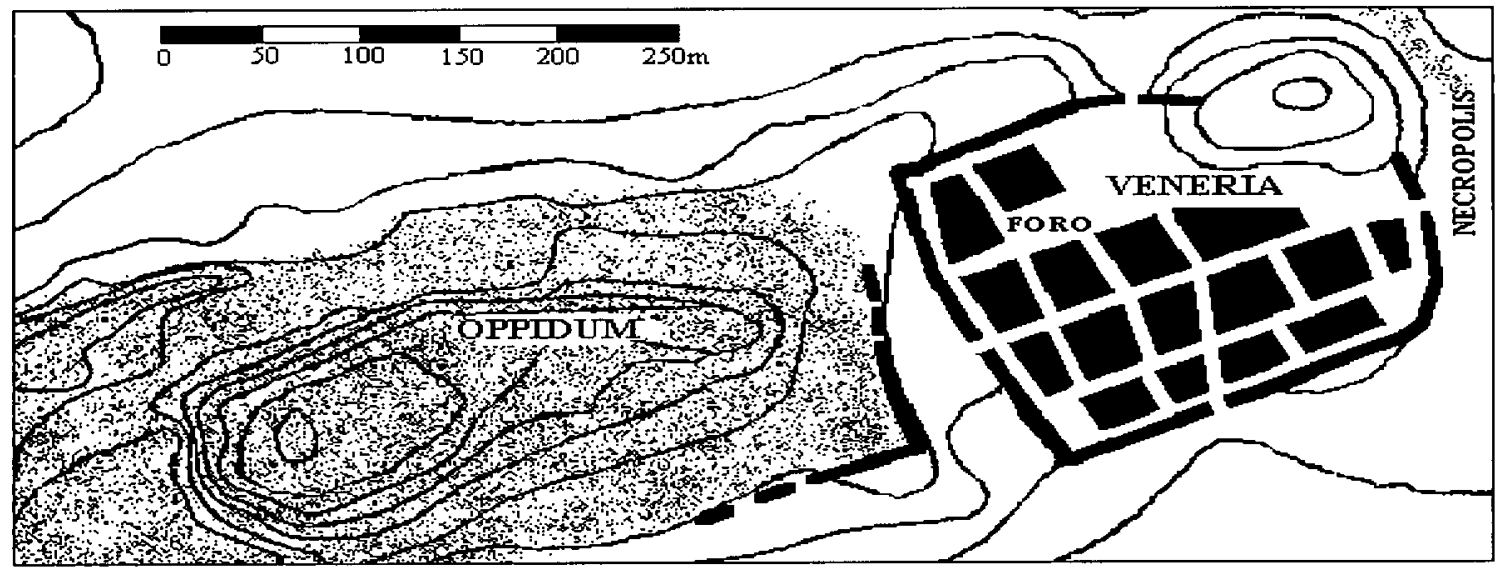

Figura 6. El oppidum Nabrissa y la Veneria romana.

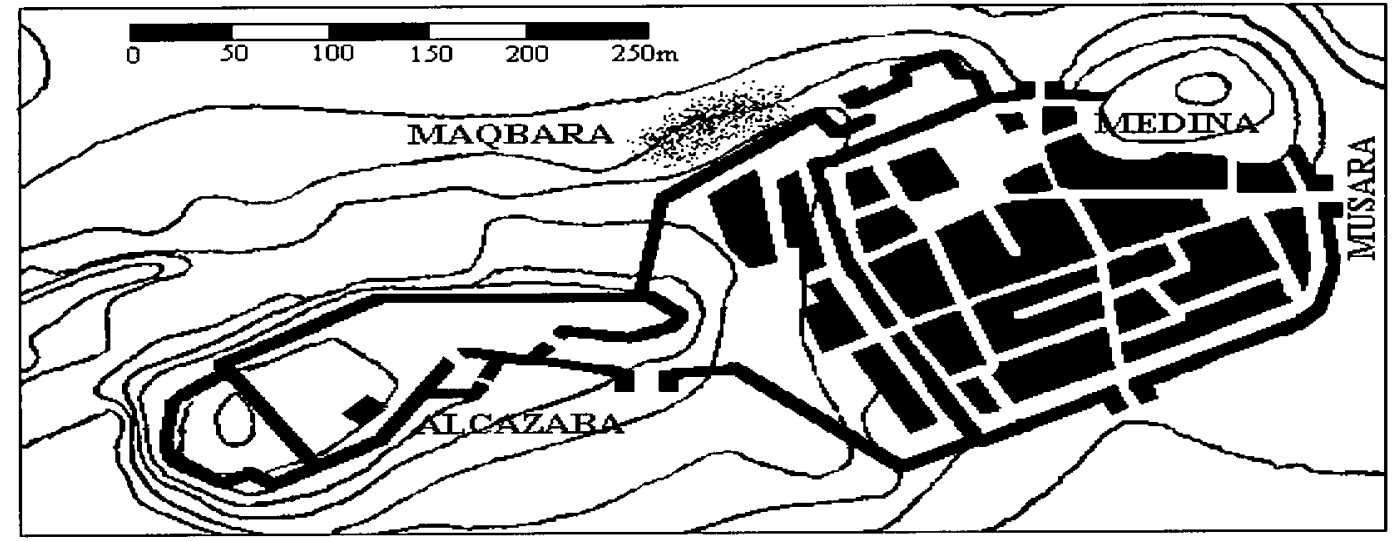

Figura 7. Lebrija almohade. 


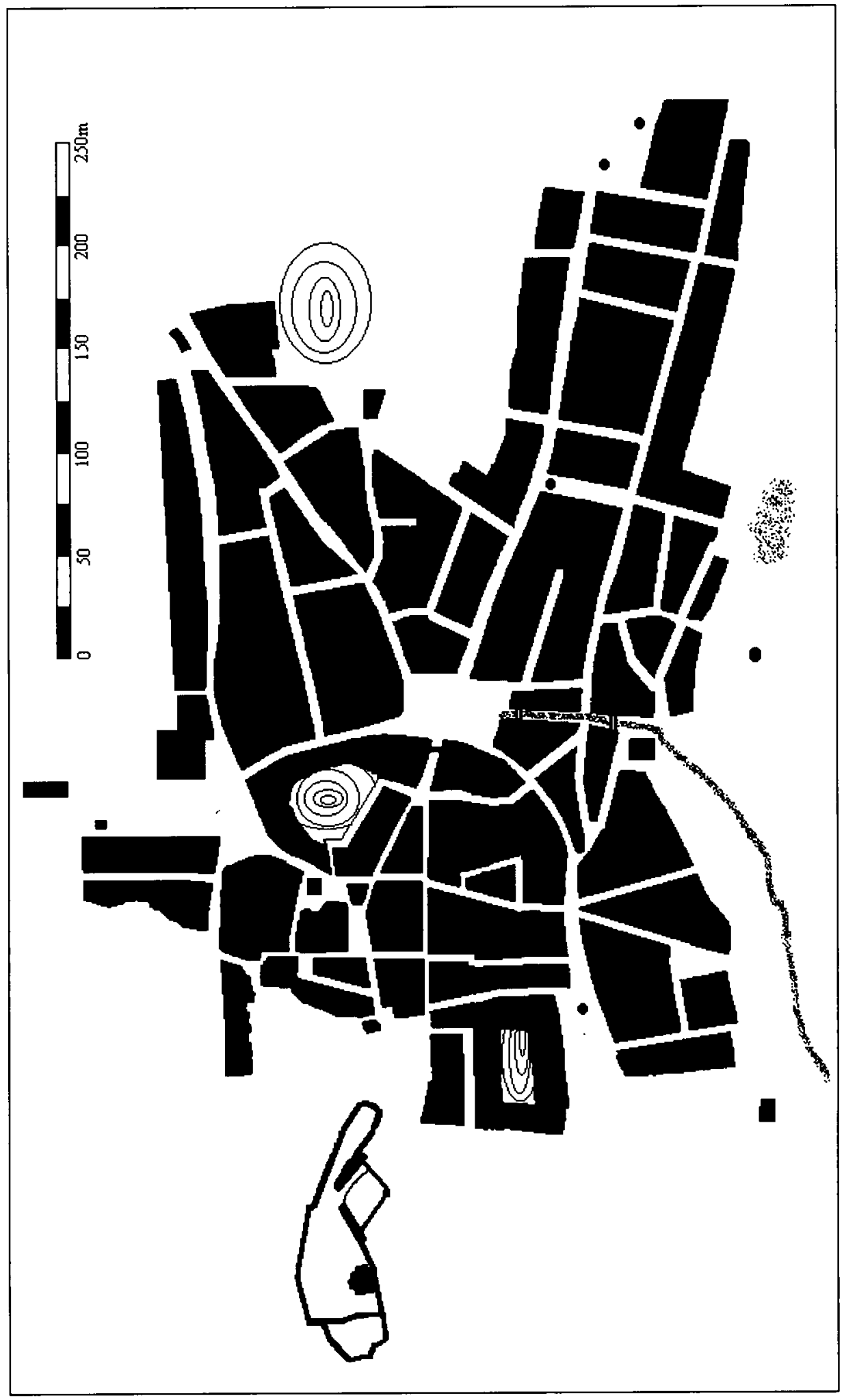

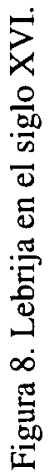

